International Journal of Economics, Business and Accounting Research (IJEBAR)

Peer Reviewed - International Journal

Vol-3, Issue-4, 2019 (IJEBAR)

E-ISSN: 2614-1280 P-ISSN 2622-4771

https://jurnal.stie-aas.ac.id/index.php/IJEBAR

\title{
FACTORS THAT AFFECT INEQUALITY DISTRIBUTION INCOME IN CENTRAL JAVA
}

\author{
Soeharjoto \\ Universitas Trisakti, Jakarta, Indonesia \\ Email: soeharjoto@trisakti.ac.id
}

\begin{abstract}
Sustainable development can increase economic growth and income distribution more equitable. This become a challenge for the Central Java province with a large area of population in overcoming income distribution inequality. Aims of this study is to determine factors that influence income distribution inequality in Central Java. Panel data regression method with fixed effect models are used. Inequality income distribution as a dependent variable and the independent variables are GRDP, agglomeration of industrial sector, agglomeration of trade, agglomeration of agriculture, inflation, level of labor force participation, and domestic investment. Results show that industrial agglomeration has a positive and significant effect on inequality income between districts and cities in Central Java. GRDP, agricultural agglomeration and level of labor force participation have a negative and significant effect on inequality income between districts and cities in Central Java. The influence of the trade agglomeration, inflation, and domestic investment is not significant to inequality income between districts and cities in Central Java.
\end{abstract}

Keywords: $\quad$ Inequality of income distribution, GRDP, Agglomeration, Inflation, level of labor force participation, and domestic investment.

\section{Introduction}

Implementation of development economic field in Indonesia, has implemented various strategies. The strategy adopted by the government is to accelerate development, by changing development policies from centralization to decentralization (Soeharjoto, 2019). It has an impact on the implementation of development in the regions. For this reason, needs to be coordinate and synergy between the central and regional governments and the community in managing resources (Soeharjoto et. al., 2020). This pattern, can be in form of partnership, so it will absorb labor, which will ultimately increase the acceleration of economic growth and equitable distribution of income distribution.

Central Java Province has a large area with a dense population. Condition of this unique province, still has relatively stable economy (Soekapdjo et. al., 2020). Though their Gross regional domestic product (GRDP) per capita below the national level, it has lower inflation than the national level. GRDP in 2010-2018, has increased with fluctuating growth trends. Average GRDP of Rp. 772,146.79 billion, which in 2010 growth from Rp. 623,224.6 billion to Rp. 940,759.8 billion in 2018. Average GRDP growth is 5.29 percent, with the highest was in 2011 at 5.59 percent and the lowest was in 2012 at 4.92 percent. Population growth has a declining trend, with an average of 0.77 percent . The highest population growth was $0.87 \%$ at 2011 and the lowest was $0.68 \%$ in 2018 . 
International Journal of Economics, Business and Accounting Research (IJEBAR)

Peer Reviewed - International Journal

Vol-3, Issue-4, 2019 (IJEBAR)

E-ISSN: 2614-1280 P-ISSN 2622-4771

https://jurnal.stie-aas.ac.id/index.php/IJEBAR

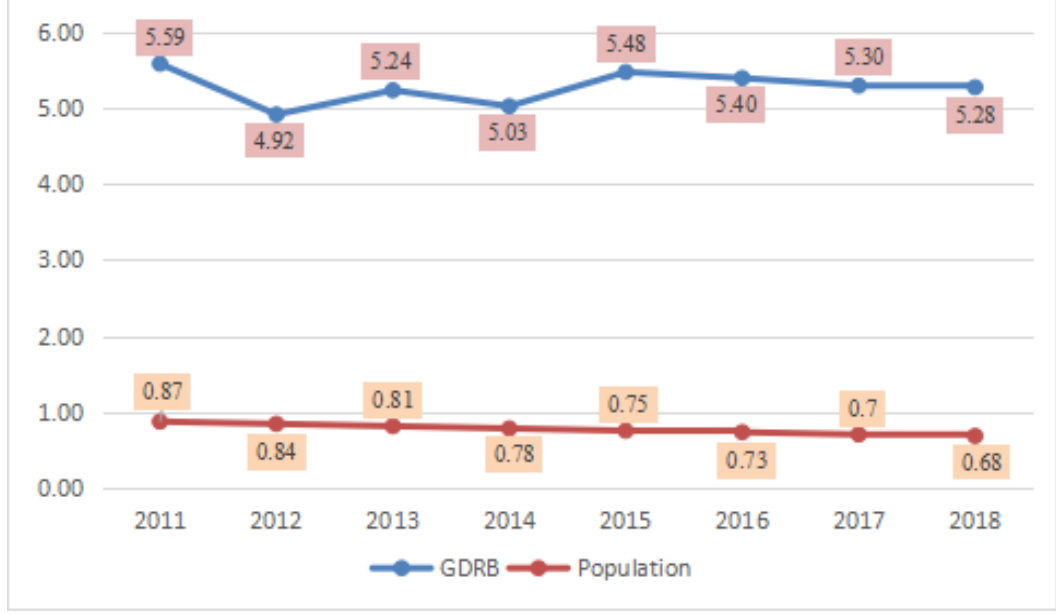

Figure 1. GRDP growth based on constant prices at 2010 and Population in Central Java (Percent) Source: BPS

GRDP growth in Central Java in 2010-2018 has a fluctuating trend with population growth that has a downward trend. GRDP growth is higher than population growth, with an average labor force participation rate of 68.93 percent, as well as an average consumer price index (CPI) of 119.89 percent, which has an impact on reducing inequality in income distribution. This, causing inequality at development has a declining trend, with an average of 0.69 percent and a standard deviation of 0.014 percent.

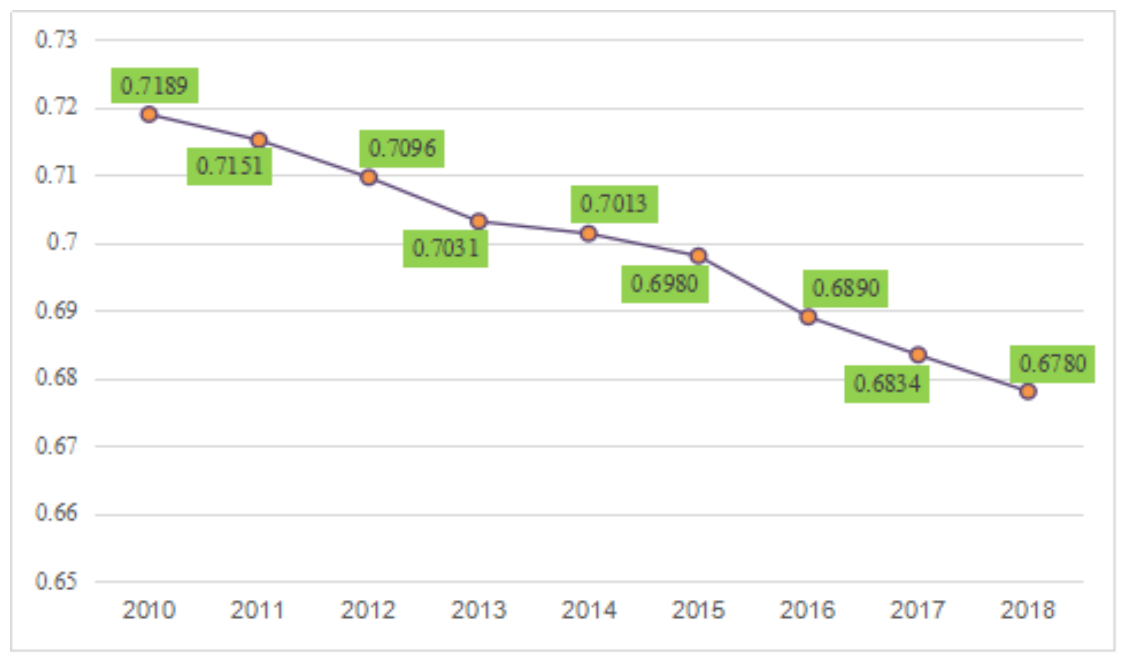

Figure 2. Inequality Development in Central Java (Percent)

Source: BPS, processed data

Economic growth in the process can be divided into two main aspects are growth of Gross Domestic Product and population growth (Smith, 1969). For this reason, it is necessary to have a synergy between them. Hope that economic growth can increase country capacity in the long run, so it can provide various needs of the community (Kuznet, 1973). At the beginning of development, community income distribution is not evenly distributed, but at a certain level of the impact of development, it will result in an even distribution of income. This is happens because at the short term, there is a positive relationship between economic growth and the unequal distribution of income. However, the relationship becomes negative in the long run. 
International Journal of Economics, Business and Accounting Research (IJEBAR)

Peer Reviewed - International Journal

Vol-3, Issue-4, 2019 (IJEBAR)

E-ISSN: 2614-1280 P-ISSN 2622-4771

https://jurnal.stie-aas.ac.id/index.php/IJEBAR

Agglomeration is formed from the behavior of economic actors in seeking profits, with the localization and urbanization (Kuncoro, 2002). Neo-classical agglomeration, assumes the existence of perfect competition so that the centripetal power of agglomeration as a pure external economy (Krugman, 1998). The centripetal power arises from the need to commute to the main business centers in each city, so it will cause a gradient of land rent from each city. According to Krugman (1998), the limitations of neo-classical theory include seeing that the external economy that encourages agglomeration is still considered a mystery (black box). In addition, the neo-classical urban system is non-spatial, which only describes the number and type of cities, but does not indicate its location.

Dynamic of externality theories believe that geographical proximity will facilitate the transmission of ideas, so technology transfer can be important for cities (Glaeser et. al., 1992). Diversity of industries that are geographically close together will support innovation and growth compared to geographical specialization.

The New Economic Geography theory seeks to reduce the effects of agglomeration from interactions between market size, transportation costs and companies increasing returns. In this case, economic agglomeration is not assumed, but is derived from economic scale interactions at the company level, transportation costs and factor mobility. New geographic economic theories emphasize the existence of circular causality mechanisms to explain the spatial concentration of economic activity (Krugman and Venables in Martin \& Gianmarco, 2001).

Research on the factors that affect inequality income has been done by several researchers. According to Kurniawan and Sugiyanto (2013), in Central Java economic growth is not significant to the level of inequality income distribution, agricultural and industrial agglomeration has a positive effect on the level of inequality income distribution, while the level of the amount of work is not significant to the level of inequality income distribution. Kiton (2019), find that at North Sumatra, agglomeration is not significant to the level of inequality income distribution. Urrahman (2012), found that investmen in West Nusa Tenggara was insignificant and agglomeration had a negative effect on the level of inequality income distribution. Didia (2016) found that in the Kedungsepur area investment and labor force participation rates were not significant to the unequal distribution of income. Dondo et. al. (2019), found that at Minahasa Regency economic growth had a positive effect on the level of inequality income distribution. Wijayanto (2016), revealed that in North Sulawesi province economic growth had a negative effect on inequality in income distribution. Pramesti and Yasa (2019), revealed that in Klungkung Regency inflation and investment had a positive effect on the level of inequality income distribution.

Central Java province, carried out the regional autonomy policy, aims to accelerate the progress of the region. This can happen because the government and the local community know the root of the problem and the solution in the area. Many of these conditions are not in line with expectations in reality, because there are several regions that are unable to manage their resources. The impact, economic growth has become increasingly uneven, resulting in an increase in inequality income distribution. Inequality of income distribution, will increasingly lead to poverty. This condition cannot be tolerated because it can have a negative impact on social and political conditions. For this reason, it is necessary to research the factors that influence inequality income in Central Java.

\section{Research Method}

This research uses panel data regression method. Data in the form of time series and cross sections from Regencies and Cities in Central Java in 2010-2018, which came from the Central Statistics Agency. Dependent variable uses inequality income distribution which is proxy by Williamson index and free variable uses GRDP, industrial agglomeration, trade agglomeration, agricultural agglomeration, inflation, labor force participation rate, domestic investment. The equation is:

$$
\mathrm{IID}_{\mathrm{it}}=\beta_{1}+\beta_{2} \mathrm{GRDP}_{\mathrm{it}}+\beta_{3} \mathrm{IA}_{\mathrm{it}}+\beta_{4} \mathrm{TA}_{\mathrm{it}}+\beta_{5} \mathrm{AA}_{\mathrm{it}}+\beta_{6} \mathrm{INF}_{\mathrm{it}}+\beta_{7} \mathrm{LLFP}_{\mathrm{it}}+\beta_{8} \mathrm{ID}_{\mathrm{it}}+\varepsilon_{\mathrm{it}}
$$

International Journal of Economics, Bussiness and Accounting Research (IJEBAR) Page 124 
International Journal of Economics, Business and Accounting Research (IJEBAR)

Peer Reviewed - International Journal

Vol-3, Issue-4, 2019 (IJEBAR)

E-ISSN: 2614-1280 P-ISSN 2622-4771

https://jurnal.stie-aas.ac.id/index.php/IJEBAR

Information:

IID : Inequality of income distribution (Williamson index).

GRDP : Gross regional domestic product.

IA : Industrial agglomeration.

TA : Trade agglomeration.

AA : Agricultural agglomeration.

INF : Inflation.

LLFP : Level of labor force participation.

DI : Domestic investment.

The Williamson index calculation uses the equation (Williamson in Akita and Kataoka, 2003):

$$
V_{w}=\frac{\sqrt{\sum_{i=1}^{n}\left(y_{i-} y\right)^{2}\left(\frac{f_{i}}{n}\right)}}{y} \quad 0<V_{w}<1
$$

Information:

$\mathrm{Vw}=$ Williamson Index.

Yi $\quad=$ GRDP district and city i per capita

y $\quad=$ GRDP province per capita.

fi $\quad=$ Number residents of district and city $\mathrm{i}$

$\mathrm{n}=$ Total population of the province.

Agglomeration calculations using equations:

$$
\text { Agi }=\text { GRDBi/GRDB toti }
$$

Information :

Agi $\quad=$ Agglomeration of district and city sector i production in Central Java.

GRDBi = Value of contribution from sector $i$ at constant 2000 prices districts and cities in Central Java.

GRDBtoti = Total value of sector $\mathrm{i}$ at the constant price of 2000 Java province The middle.

Hypothesis:

This testing is carried out to see the significance of the individual influence of the independent variables in the form of GRDP, industrial agglomeration, trade agglomeration, agricultural agglomeration, consumer price index, labor force participation rate, domestic investment in the model of the dependent variable namely inequality of proxy income distribution with the Williamson index. The hypothesis is:

1. GRDP has a negative effect on regional inequality.

2. Industrial agglomeration has a positive effect on regional inequality.

3. Trade agglomeration has a positive effect on regional inequality.

4. Agricultural agglomeration has a positive effect on regional inequality.

5. Inflation has a positive effect on regional inequality.

6. Level of labor force participation has a negative effect on regional inequality.

7. Domestic Investment has a negative effect on regional inequality.

\section{Results and Discussion}

\subsection{Results}

Inequality of income between districts and cities in Central Java produces an average value of 0.6996, means there is inequality level of income between districts and cities in Central Java is included in the high group. The standard deviation value is 1,324 , shows that the variation between income inequality 
International Journal of Economics, Business and Accounting Research (IJEBAR)

Peer Reviewed - International Journal

Vol-3, Issue-4, 2019 (IJEBAR)

E-ISSN: 2614-1280 P-ISSN 2622-4771

https://jurnal.stie-aas.ac.id/index.php/IJEBAR

from year to year is relatively small, as indicated by the Williamson index minimum value of 0.680 while the maximum value is 0.720 . The development of the Williamson index for districts and cities during the period 2010-2018, has a relatively high level of inequality income of districts and cities in Central Java province but has a declining trend.

Economic level activity is proxied through the GRDP, shows the average regency and city GRDP in 2010-2018 in Central Java of Rp. 22.0613 trillion. Standard deviation of Rp. 20,945 trillion, which shows the very high variation of GRDP between districts and cities with others. This can be seen from the minimum GRDP value of Rp. 4.01 trillion with a maximum value of $\mathrm{Rp} 131.14$ trillion. The development of regency and city GRDP in Central Java in 2010-2018, has a level of economic activity between regencies and cities with an increasing trend.

Manufacturing sector agglomeration, has an average value of 2.8571 percent, means that the average contribution of the district and city manufacturing sector to Central Java in 2010-2018 is still relatively small. Standard deviation value is 4.5658 percent, showing the relatively high variation of manufacturing sector agglomeration data between districts and cities. Minimum value is 0.270 percent and the maximum value is 25.66 percent. The development of the agglomeration of the average manufacturing sector in regencies and cities in 2010-2018 had a decreasing trend in the manufacturing sector agglomeration, which showed a smaller agglomeration gap between districts and cities.

Trade sector agglomeration, produces an average value of 2.8571 percent, which means the average contribution of the district and city trade sector in Central Java in 2010-2018 is still relatively small. The standard deviation value is 2.2318 percent, which shows that the variation of the agglomeration of trade sector data between regencies and cities is relatively high. Minimum value is 0.73 percent and the maximum value is 14.48 percent. Development of the volatility of the agglomeration of the district and city diversification sectors at Central Java in 2010-2018, has a declining trend, which shows the gap in the agglomeration of the trade sector between districts and cities getting smaller.

Agglomeration of the agricultural sector, has an average value of 2.8571 percent with a standard deviation of 1,767 percent, which shows a relatively high variation in the agglomeration of the agricultural sector between districts and cities. Minimum value is 0.8 percent with a maximum value of 9.63 percent. Development of the agglomeration of the regency and city agriculture sector in Central Java in 2010-2018 has an increasing upward trend, which shows the agglomeration gap is getting bigger at the trade sector.

Inflation procured through GRDP Deflator has an average value of 119.89 percent with a standard deviation of 12,670 percent, which shows that inflation between regencies and cities is relatively high. The minimum value is 97.17 percent with a maximum value of 146.46 percent. Inflation development of district and city in Central Java in 2010-2018, has an increasing trend.

Level of labor force participation at district and city in Central Java, have an average value of 69,955 percent with a standard deviation of 3,511 percent, which shows a relatively low variation in level of labor force participation between districts and cities. Minimum level of labor force participation value is 60.17 percent with a minimum value of 79.47 percent. Development of Regency and city level of labor force participation in Central Java in 2010-2018, has volatile volatility with a downward trend.

Districts and cities in Central Java domestic investment, have an average value of Rp. 4,5574 billion with a standard deviation of Rp. 13,053 billion, which shows a relatively high variation in domestic investment between districts and cities. Minimum value of zero with a maximum value of Rp. 148.46 billion. Development of regency and municipal domestic investment in Central Java in 2010-2017 has an upward trend and a significant increase occurred in 2015-2016. However, decline in 2018.

Chow test results obtained the probability value of the cross section chi-square of $0,000<0.05$, so that the right model Fixed Effect Model (FEM). The Hausman test obtained the probability value of a random cross section of $0.000<0.05$, so that the right model is the Fixed Effect Model (FEM). 
International Journal of Economics, Business and Accounting Research (IJEBAR)

Peer Reviewed - International Journal

Vol-3, Issue-4, 2019 (IJEBAR)

E-ISSN: 2614-1280 P-ISSN 2622-4771

https://jurnal.stie-aas.ac.id/index.php/IJEBAR

Results of processing fit model for the income inequality model between regencies and cities in Central Java, obtained adjusted R-Square value of 0.944916, which means variations of GRDP, industrial sector agglomeration, trade sector agglomeration, agricultural sector agglomeration, inflation, level of labor force participation and domestic investment able to explain the variation or behavior of income inequality is 94.4961 percent, while the remaining 5.5039 percent is a variation of other variables that affect inequality income between districts and cities in Central Java, but is not included in the model. Results indicate that inequality income model between regencies and cities in Central Java has a goodness of fit model.

Global test results for inequality income models obtained probability values from $\mathrm{F}$ statistics of $0.0000<0.05$ which means it is proven that there is at least one of the GRDP, industrial sector agglomeration, trade sector agglomeration, agricultural sector agglomeration, inflation, level of labor force participation and domestic investment significantly influence inequality income between regencies and cities in Central Java. Table 1 show the individual test results based on the Fixed Effect Model.

Tabel 1. Results of Estimated Revenue Inequality Model Between Regencies and Cities in Central Java

Income Inequality Model Between Regencies and Cities in Central Java

Variable

Coefisien t-statistic P-value Results

\begin{tabular}{|c|c|c|c|c|}
\hline GRDP & $\begin{array}{c}- \\
0.000321 \\
\end{array}$ & $\begin{array}{c}- \\
4.933221 \\
\end{array}$ & 0.0000 & $\begin{array}{l}\text { Hypothesis } \\
\text { accepted }\end{array}$ \\
\hline Industrial Agglomeration & 0.001924 & 5.754093 & 0.0000 & $\begin{array}{l}\text { Hypothesis } \\
\text { accepted }\end{array}$ \\
\hline Trade Agglomeration & 0.001016 & 0.769461 & 0.2211 & Hypothesis rejected \\
\hline Agricultural Agglomeration & $\stackrel{-}{-}$ & $\begin{array}{c}- \\
2.419142 \\
\end{array}$ & 0.0081 & $\begin{array}{l}\text { Hypothesis } \\
\text { accepted }\end{array}$ \\
\hline Inflation & $\begin{array}{c}- \\
0.000993\end{array}$ & $\begin{array}{c}- \\
45.10142\end{array}$ & 0.0000 & Hypothesis rejected \\
\hline $\begin{array}{l}\text { Level of labor force } \\
\text { participation }\end{array}$ & $\begin{array}{c}- \\
0.000148\end{array}$ & $\begin{array}{c}- \\
1.680359\end{array}$ & 0.0470 & $\begin{array}{l}\text { Hypothesis } \\
\text { accepted }\end{array}$ \\
\hline Domestic investment & $\begin{array}{c}-9.44 \mathrm{E}- \\
06 \\
\end{array}$ & $\begin{array}{c}- \\
0.504564 \\
\end{array}$ & 0.3071 & Hypothesis rejected \\
\hline
\end{tabular}

Source : processed data

GRDP has an estimated coefficient value of minus 0.000321, means an increase in the level of economic activity will reduce inequality income between districts and cities in Central Java and vice versa, a decreased level of economic activity will increase inequality income between districts and cities in Central Java. The p-value is $0.0000<0.05$. means that the level of economic activity has a negative effect on inequality income between districts and cities in Central Java.

Agglomeration at industrial sector has an estimated coefficient value of 0.001924 , means an increase in this sector will increase inequality income between districts and cities in Central Java and vice versa, decreasing agglomeration of industrial sectors will reduce inequality income between districts and cities in Central Java. The p-value of $0.0000<0.05$, means that the agglomeration of the 
International Journal of Economics, Business and Accounting Research (IJEBAR)

Peer Reviewed - International Journal

Vol-3, Issue-4, 2019 (IJEBAR)

E-ISSN: 2614-1280 P-ISSN 2622-4771

https://jurnal.stie-aas.ac.id/index.php/IJEBAR

industrial sector has a positive effect on inequality income between districts and cities in Central Java is proven.

Agglomeration at trade sector has an estimated coefficient value of 0.001016 , means increasing in this sector will increase inequality income between districts and cities in Central Java and vice versa, decreasing agglomeration of trade sector will reduce inequality income between districts and cities in Central Java. The p-value of $0.2211<0.05$, means that the agglomeration of the trade sector has a positive effect on inequality income between districts and cities in Central Java is not proven.

Agglomeration of the agricultural sector has an estimated coefficient value of minus 0.000993 , means an increase in agglomeration of the agricultural sector will reduce inequality income between districts and cities in Central Java and vice versa, decreasing agglomeration of the agricultural sector will increase inequality income between districts and cities in Central Java. The p-value of $0.0081<0.05$, means that the agglomeration of the agricultural sector has a negative effect on inequality income between districts and cities in Central Java is proven.

Estimated coefficient value of Inflation is minus 0.000993, means rising inflation will reduce inequality income between districts and cities in Central Java and vice versa, decreasing inflation will increase inequality income between districts and cities in Central Java. The p-value of $0.0000<0.05$, means inflation has a positive effect on inequality income between districts and cities in Central Java is not proven.

Estimated coefficient value of level of labor participation is minus 0.000148 , means an increase level of labor participation in will reduce inequality income between districts and cities in Central Java and vice versa, decreasing level of labor participation will increase inequality income between districts and cities in Central Java. The p-value of $0.0470>0.05$, means that level of labor participation has a negative effect on inequality income between districts and cities in Central Java is proven.

Estimated coefficient value of domestic investment is minus $9.44 \mathrm{E}-06$, means an increase in domestic investment will reduce inequality income between districts and cities in Central Java and vice versa, decreasing domestic investment will increase inequality income between districts and cities in Central Java province. The p-value is $0.3071>0.05$, means that domestic investment has a negative effect on inequality income between districts and cities in Central Java is not proven.

\subsection{Discussion}

GRDP, industrial and agricultural agglomeration, level of labor force participation have an influence and significant effect on the unequal distribution of income between regencies and cities in Central Java, but the agglomeration of trade, inflation and domestic investment is not significant. GRDP at Central Java indicates an increase in community welfare, it will have an impact on increasing public demand for goods and services, resulting in an increase in community transactions, thus making the income distribution evenly distributed. Change in interest of young generation at development of skills from the agricultural sector to industry, so with the agglomeration of industry will absorb the workforce of the young generation, but they get competition from the migration of surrounding communities, moreover the developed industry is capital-intensive, so it's a tight competition, especially with the expansion of industry will reduce agricultural land, industrial agglomeration consequence will only make the income distribution more uneven. Agriculture is the main source of livelihood of the local community, so that agricultural agglomeration can accelerate the increase in community income, which results in a more equitable distribution of income. The large number of level of labor force participation will increase the income of the community so it will cause increase their welfare, which results in an even distribution of income.

Trade agglomeration, inflation and domestic investment is not significant. This is because Central Java is an agricultural area, so trade is not the main source of community livelihood, so trade agglomeration is not significant to the unequal distribution of income. Inflation fluctuations are not too volatile and people live in simplicity, so that inflation is not significant to the unequal distribution of income. Domestic Investment that is conducted is not in accordance with the skills of its human

International Journal of Economics, Bussiness and Accounting Research (IJEBAR) Page 128 
International Journal of Economics, Business and Accounting Research (IJEBAR)

Peer Reviewed - International Journal

Vol-3, Issue-4, 2019 (IJEBAR)

E-ISSN: 2614-1280 P-ISSN 2622-4771

https://jurnal.stie-aas.ac.id/index.php/IJEBAR

resources, so the existence of domestic investment is not significant to the unequal distribution of income.

Central Java Province can increase the distribution of income more equitably by optimizing the use of natural and human resources in accordance with local customs, so that it will further increase GRDP, agricultural agglomeration, and level of labor force participation. However, for domestic investment, trade and industry agglomeration is directed at the use of local resources and the local government develops human resources skills in accordance with the skills needs of investors. The government and the community need to continue to maintain consumption patterns that are in accordance with their needs, so that inflation can be stable which impacts on maintaining the real purchasing power of the people, which will ultimately increase the welfare of the people.

\section{Conclusion}

Research the factors that influence the income distribution inequality in Central Java using panel data regression with fixed effect models. Inequality of income distribution is a dependent variable with the independent variable GRDP, industrial agglomeration, trade agglomeration, agricultural agglomeration, inflation, level of labor force participation, and domestic investment. The results of industrial agglomeration has a positive and significant effect on income inequality between districts and cities in Central Java. GRDP, agricultural agglomeration and level of labor force participation have a negative and significant effect on income inequality between districts and cities in Central Java. The influence of the trade sector agglomeration, inflation, and domestic investment is not significant to income inequality between districts and cities in Central Java. To overcome the unequal distribution of income, the government needs to develop education and training programs, make investment policies that use resources and accommodate the workforce of the local community, maintain inflation stability to support the attractiveness of investors and maintain people's purchasing power.

\section{Reference}

Akita, T. \& Kataoka, M. (2003). Regional Income Inequality in the Post War Japan. ERSA Conference Paper, ersa03p480. 43rd Congress of the European Regional Science Association (ERSA) at Jyvaskyla, Finland, August 27-30.

Didia, K. A. (2016). Analisis Ketimpangan Pembangunan di Kawasan Kedungsepur. Economics Deveopment Anaysis Journal, 5(1), 101-108.

Dondo, T. C., Benu, N. M. \& Manginsela, E. P. (2019). Faktor-Faktor yang Mempengaruhi Ketimpangan Distribusi Pendapatan Rumah Tangga di Kabupaten Minahasa. AGRIRUD, 1(1), $60-70$.

Glaeser, E., Kallal, H. D., Scheinkman, J. \& Shleifer, A.. (1992). Growth in Cities. Journal of Political Economy, 100(6),1126-1152.

Kuznets, S. (1973). Modern Economic Growth: Findings and Reflections. The American Economic Review, 63(3). 247-258.

Krugman, P. (1998). Space: the Final Frontier. Journal of Economic Perspectives, 12(2),161-174.

Kuncoro, M. (2002). Analisis Spasial dan Regional,Studi Aglomerasi dan Kluster Industri Indonesia. UPP AMP YKPN.Yogyakarta.

Kurniawan, B. R. A. \& Sugiyanto, FX. (2013). Pengaruh Pertumbuhan Ekonomi, Share Sektor Industri dan Pertanian serta Tingkat Jumlah Orang Yang Bekerja Terhadap Ketimpangan Wilayah Antar Kabupaten/Kota di Jawa Tengah Tahun 2002-2010. Diponegoro Journal of Economics, 2(1). 1-14.

Kiton, M. A. (2019). Analisis Ketimpangan Pembangunan Ekonomi di Provinsi Sumatera Utara. Jurnal Ilmiah Smart, 3(2),68 - 80.

Martin, P. \& Ottaviano, G. I. P. (2001). Growth and Agglomeration. International Economic Review. 42(4), 947-968. 
International Journal of Economics, Business and Accounting Research (IJEBAR)

Peer Reviewed - International Journal

Vol-3, Issue-4, 2019 (IJEBAR)

E-ISSN: 2614-1280 P-ISSN 2622-4771

https://jurnal.stie-aas.ac.id/index.php/IJEBAR

Pramesti, D. A. D. G. \& Yasa, I. N. M. (2019). Pengaruh Investasi dan Inflasi Terhadap Pertumbuhan Ekonomi dan Ketimpangan Distribusi Pendapatan di Kabupaten Klungkung. E-Jurnal EP Unud, $8(11), 2562-2590$.

Smith, A. (1969). An Inquiry into the Nature and Causes of the Wealth of Nations. New Macmi York: Kennikat Press. (Original work published 1786)

Soekapdjo, S. Debbie Aryani Tribudhi, Dini Hariyanti, Lucky Nugroho. (2020). Factors Affecting Economic Growth in Central Java. International Journal of Commerce and Finance, 6(1). 155165.

Soeharjoto. (2019). Kemampuan dan kinerja keuangan provinsi kalimantan. AKUNTABEL, 15(2). 131-138. DOI: http://dx.doi.org/10.29264/jakt.v15i2.4472

Soeharjoto, Tribudhi, D. A. \& Nugroho, L. (2020). Fiscal Regency and City Capacity in East Kalimantan in The Era of Regional Autonomy. International Journal of Economics, Business and Accounting Research, 4(2). 23-30. DOI : 10.29040/ijebar.v4i02.973

Urrahman, A. (2012). Analisis Ketimpangan Pembangunan Wilayah di Provinsi Nusa Tenggara Barat Periode 2006-2010. Jurnal Ilmiah Mahasiswa FEB, 1(1).

Wijayanto, A. T. (2016). Analisis Keterkaitan Pertumbuhan Ekonomi, Ketimpangan Pendapatan dan Pengentasan Kemiskinan di Provinsi Sulawesi Utara Tahun 2000-2010. Jurnal Berkala Ilmiah Efisiensi, 16(2). 418-428. 